\title{
CXorf67 wt Allele
}

National Cancer Institute

\section{Source}

National Cancer Institute. CXorf67 wt Allele. NCI Thesaurus. Code C111978.

Human CXorf67 wild-type allele is located in the vicinity of Xp11.22 and is approximately 2 $\mathrm{kb}$ in length. This allele, which encodes uncharacterized protein CXorf67, has no known function. A fusion of this gene and the MBTD1 gene may be associated with low-grade endometrial stromal sarcomas. 